\title{
N73 36479
}

\section{NASA TECHNICAL}

\section{MEMORANDUM}

NASA TM $X-68264$

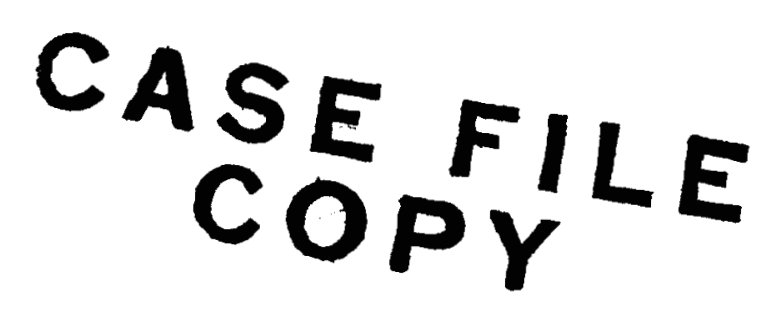

PARAMETRIC STUDY OF THE LUBRICATION OF THRUST

LOADED 120-MM BORE B ALL BEARINGS TO 3 MILLION DN

by H. Signer, E. N. Bamberger, and E. V. Zaretsky

Lewis Research Center

Cleveland, Ohio 44135

TECH NICAL PAPER proposed for presentation at

Joint Lubrication Conference cosponsored by the American

Society of Lubrication Engineers and the American

Society of Mechanical Engineers

Atlanta, Georgia, October 16-18, 1973 


\section{PARAMETRIC STUDY OF THE LUBRICATION OF THRUST LOADED 120-MM}

BORE BALL BEARINGS TO 3 MILLION DN

by H. Signer ${ }^{*}$, E. N. Bamberger ${ }^{* *}$, and E. V. Zaretsky

Lewis Research Center

ABSTRACT

A parametric study was performed with $120-\mathrm{mm}$ bore angular-contact ball bearings under varying thrust loads, bearing and lubricant temperatures, and cooling and lubricant flow rates. Contact angles were nominally $20^{\circ}$ and $24^{\circ}$ with bearing speeds to 3 million DN. Endurance tests were run at 3 million DN and a temperature of $492 \mathrm{~K}\left(425^{\circ} \mathrm{F}\right)$ with 10 bearings having a nominal $24^{\circ}$ contact angle at a thrust load of $22241 \mathrm{~N}(5000 \mathrm{lb})$. Bearing operating temperature, differences in temperatures between the inner and outer races, and bearing power consumption can be tuned to any desirable operating requirement by varying 4 parameters. These parameters are outer-race cooling, inner-race cooling, lubricant flow to the inner race and oil inlet temperature. Preliminary endurance tests at 3 million $D N$ and $492 \mathrm{~K}\left(425^{\circ} \mathrm{F}\right)$ indicate that long term bearing operation can be achieved with a high degree of reliability.

\footnotetext{
*Industrial Tectonics, Inc., Compton, California

** Genera1 Electric Co., Cincinnati, Ohio

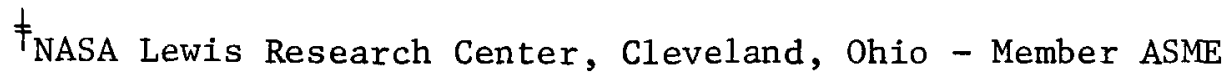




\section{INTRODUCTION}

Advanced air breathing engines for high-speed aircraft for the 1980 's are expected to operate with bearing temperatures near $492 \mathrm{~K}$ $\left(425^{\circ} \mathrm{F}\right)$ and at speeds approaching 3 million DN. (DN is a bearing speed parameter and is equal to the product of the bearing bore in millimeter and the shaft speed in rpm.) In support of these engines, as well as for similar high performance oriented bearing applications, a reliable bearing-lubricant system is required. Such a system requires essentially three key items. These are, a suitable lubricant, a reliable bearing structural material, and an optimized bearing design coupled with the proper operational parameters needed to sustain ultrahigh speeds.

Over the past decade several new classes of lubricants were developed and evaluated, which extended the upper temperature range of lubricating fluids $[1-4]^{1}$. Of these, the poly-ester and tetra-ester fluids have proven to be most useful and applicable in typical airbreathing environments, and consequently have been widely accepted in current commercial and military applications [5]. These fluids have good thermal stability at temperatures to $505 \mathrm{~K}\left(450^{\circ} \mathrm{F}\right)$. Bearing life at $492 \mathrm{~K}\left(425^{\circ} \mathrm{F}\right)$ with the tetra-esters exceeded AFBMA-predicted (catalogue) life by a factor in excess of four [3]. When test oil in [3] was replaced at a rate approximating the replenishment rate in

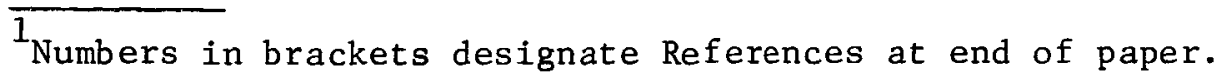


actual commercial engine usage, no significant increase in lubricant viscosity or acidity with time was observed at $492 \mathrm{~K}\left(425^{\circ} \mathrm{F}\right)$.

Research reported in [6] indicated that AISI M-50 steel can produce the most favorable life results at elevated temperatures when compared with other high-speed or high-temperature steels such asin-1, A: $\mathrm{M}-10$, WB-49, etc. Rolling-element bearing tests to $589 \mathrm{~K}\left(600^{\circ} \mathrm{F}\right)$ with the AISI M-50 steel and a synthetic paraffinic oil produced lives in excess of 13 times the AFBMA predicted 1ife.

In conventional rolling-element bearings, both metallic and nonmetallic cages have found widespread use. Precision bearings, such as those used for aircraft applications, are usually equipped with cages machined from iron or copper base alloys. Where marginal lubrication is suspected during operation, silver plating of the cage material has been used to attenuate the detrimental effects of intermittent or momentary metal to metal contact. The bearing tests reported in [1-4] successfully utilized a cage material made of a nickel base alloy (AMS 4892). In most critical high-temperature, high-load and high-speed aircraft applications, the cages are a carbon steel (AISI 4340 or similar) hardened to $A$ BCke 33 and silver plated for extra protection. With the tetra-ester lubricant and the $A$ M-50 steel, two of the three key elements essential to successful large-diameter, high-1oad and ultrahigh-speed bearing operation are now specified. However, highspeed bearing operation in the range of 3 million DN requires more than the proper lubricant and bearing material. Heat generation within the bearing itself is extremely critical, as is component loading due to 
centrifugal effects. Jones [7-9] first considered speed effects on bearing life and dynamics without considering the effect of the lubricant. Subsequently, Harris $[10,11]$ expanded these bearing analyses including lubricant effects.

At high speed, the effect of centrifugal loading of the rolling elements against the outer race of the bearing becomes extremely important. Theoretical life calculations for a 150-mm bore angularcontact ball bearing operating at 3 million DN (20 000 rpm) predict that this bearing has approximately 20\% AFBMA-calculated 1ife [12]. This decrease in predicted life is due to the increased stress in the outer race caused by centrifugal effects. The expected final result is extremely short bearing life at speeds much above 2 million DN both in actual running time $(h r)$ and in total bearing inner-race revolutions. Another problem of operating bearings at high speed is the need to adequately cool the bearing components because of excessive heat generation. A method which has been used successfully to 3 million DN is cooling lubricant applied under the race [13]. In this method lubricant is centrifugally injected through the split inner-race and shoulders of an angular-contract ball bearing by means of a plurality of radial holes. As a result, both the cooling and lubricant function is ac complished.

The research reported herein, which is based on the work reported in $[14,15]$, was undertaken to investigate the performance of optimally designed $120-\mathrm{mm}$ bore angular - contact ball bearings at speeds to 3 million DN. The primary objectives were to (a) determine the operating 
characteristics under variable lubricant flow conditions at 3 million DN, (b) determine the effect of speed and load on bearing performance and (c) conduct preliminary bearing endurance tests at 3 million DN and at a temperature of $492 \mathrm{~K}\left(425^{\circ} \mathrm{F}\right)$.

HIGH* SPEED BEARING TESTER

A schematic of the high-speed, high-temperature bearing tester used in these tests is shown in 1 . This tester is described in detail in $[1,2]$ and has been subsequently modified to operate at speeds of $25000 \mathrm{rpm}$. The tester consists of a shaft to which two test bearings are attached. Loading is supplied through a system of ten springs which apply a thrust load to the bearings. Dual flat belts drive the test spindle from a $75 \mathrm{~kW}(100 \mathrm{hp})$ fixed speed electric motor. The drive motor is mounted to an adjustable base, so that drive pulleys for 12000 to $25000 \mathrm{rpm}$ can be used with the same drive belts. The drive motor is controlled by a reduced voltage auto-transformer starter which permits a selection of the motor acceleration rate during start-up. This control protects the bearings efficiently from undesirable acceleration

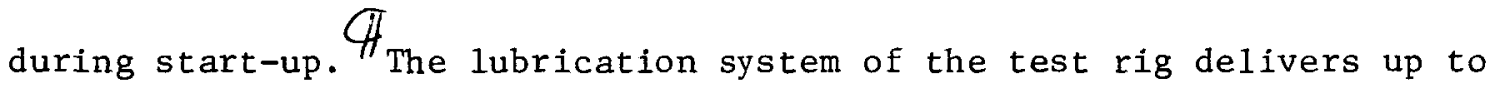
$2.8 \times 10^{-2}$ cubic meters ( 7.5 gallons). There are three lubricant 1oops in the system. The oil flow in each loop is metered by adjustable flow control valves and can be individually measured by a flow rate indicator without interruption to the machine operation. Two of these loops are shown in $: 2$. The first of these loops supplies cooling oil to the test bearing outer race and is designated $C_{0} \cdot$ The second loop is divided by a lubricant manifold which feeds individual annular grooves or channels 
at the shaft internal diameter proportioning the amount of oil which is to lubricate and/or cool each bearing inner race. $L_{i}$ designates the oil flow to the bearing through a plurality of radial holes in the center of the split inner race. $C_{i}$ designates the lubricant utilized to cool the bearing inner race and lubricate the contact of the cage with the race land through a plurality of radial holes in the inner-race shoulder. The lubricant system permits a selection of various lubricant schemes, including bearing lubrication through the inner-race $s, i, i b-$ rication of the cage-race shoulder contact region, the application of inner- and/or outer-race cooling, and a selection of any desired flow ratio for cooling and lubrication as well as the conventional lubrication through jets. The third lubricant loop is fed into the slave bearing which supports the shaft (not shown in Figs. 1 and 2). By the system of valves and manifolds previously discussed an unlimited number of combinations of oil flows can be achieved to evaluate various conditions. Consequently, values of $\mathrm{L}_{i}, \mathrm{C}_{i}$, and $\mathrm{C}_{0}$ can be independent of each other. The machine instrumentation includes the standard protective circuits which shut down a test when a bearing failure occurs, or if any of the test parameters deviate from the programmed conditions. Measurements were made of bearing inner-race speed, bearing cage speed, test spindle

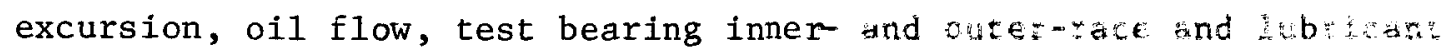
temperatures, and machine vibration level. The speed and spindle excursion measurements were made with proximity probes and displayed by numerical read-out and oscilloscope, respectively. The oil flow was established by a flow meter, and bearing outerme and lubricant inlet and 
outlet temperatures were measured by thermocouples and continuously recorded by a strip chart recorder. The inner-race temperature of the front test bearing was measured with an infrared pyrometer.

TEST BEARINGS

The test bearings were $\mathrm{ABEC}-5$ grade, split inner-race $120-\mathrm{mm}$ bore ball bearings. The inner and outer races, as well as the balls were manufactured from one heat of double vacuum-me1ted (vacuum-induction me1ted consumable electrode vacuum reme1ted) AISI M-50 stee1. The chemical analysis of the particular heat is shown in table 2 . The nominal hardness of the balls and races was Rockwell C-63 at room temperature. Each bearing contained 15 balls, $2.0638 \mathrm{~cm}(13 / 16 \mathrm{in.})$ in diameter. The cage was a one piece inner-land riding type, made out of an Rockwe.l c tatdness iron base alloy (AMS 6415) heat-treated to a $\bigcap^{r a n g e}$ of 28 . 55 and hating a $0.005 \mathrm{~cm}(0.002$ in.) maximum thickness of silver plate (AMS 2410). The cage balance was $3 \mathrm{gm}-\mathrm{cm}(0.042 \mathrm{oz}-\mathrm{in}$.$) .$

The retained austenite content of the ball and race material was less than 3 percent. The inner- and outer-race curvatures were 54 and 52 percent, respectively. Al1 components with the exception of the cage were matched within \pm one Rockwel1-C point. This matching assured a nominal differential hardness in all bearings (i.e., the ball hardness minus the race hardness, commonly called $\Delta H$ ) of zero [16]. Surface finish of the balls was $2.5 \mu \mathrm{cm}$ ( 1 microinch) AA and the inner and ouit raceways were held to a $5 \mu \mathrm{cm}$ (2 microinch) AA maximum surface finish. A photograph of the test bearing is shown in Fis-3. The bet:ing design permitted under-race lubrication by virtue of radial slots 
machined into the halves of the split inner races. It had been shown in [13] that this was the most reliable technique for lubricating high speed bearings. Provision was also made for inner-race land to cage lubrication, by the incorporation of several small diameter holes radiating from the bore of the inner ace to the center of the inner shoulder.

\section{LUBRICANT}

The oil used for the parametric studies as well as for the subsequent long-time high-speed ( 3 million DN) endurance tests, was a 5 - wentstoke neopentylpolyol (tetra) ester. This is a lype II oil, qualified to MIL-L-23699 as well as to the internal oil specifications of most major aircraft-engine producers. The major properties of subject oil are presented in Tuble $Z$ and a temperature-viscosity curve is shown in Ex.

\section{TEST PROCEDURE}

The test procedure was adjusted according to the test conditions to be evaluated. Generally, a program cycle was defined which would allow the evaluation of a number of conditions without a major interruption. With the exception of speed, all test parameters such as load, lubricant flow rate and oil temperature could be adjusted while the tester was in operation. During operation, the tester was allowed to reach equilibrium condition before the data were recorded. For the long term endurance test at 3 million DN the procedure varied on $1 \mathrm{y}$ to the extent that once the preset test parameters had been achieved no further adjustments were made. 
Power loss per bearing was determined by measuring line to line voltage and line current to the test-rig drive motor. Motor drive power was then calculated as a function of line current, reflecting bearing power usage at the various operating speeds.

Approximately $1.9 \times 10^{-3}$ cubic meters ( 0.5 gallon) of oil was replenished in every twenty-four hours of operation. This amount of oil was removed from the sump and replaced with an equal amount of fresh oil. The rate of replenishment was approximately equal to 0.3 percent per hour of the entire sump capacity. This operation was performed without interruption of the test. By closely monitoring the oil replenished, it has been shown that no significant increases in either viscosity or acid number occur, even in tests on the order of 1000 hours duration.

The rationale for this replenishment is that it serves to maintain the lubricant properties, and specifically, viscosity and acid number, at a relatively constant level. If no oil changes were made, the lubricant would present a continuously changing parameter with indeterminate effects on bearing performance. The selected replenishment rate is based on actual oil consumption rates in turbojet engines.

\section{RESULTS AND DISCUSSION}

Effect of Speed

The effect of speed on the operating characteristics of the $120-\mathrm{mm}$ bore angular-contact ball bearings are shown in 1.55 .5 and 6 so

three thrust loads. The $20^{\circ}$ and $24^{\circ}$ contact angle bearings were run at nominal speeds of $12000,16000,20000$, and $25000 \mathrm{rpm}$. Test 
conditions included an oil-inlet temperature of $428 \mathrm{~K}\left(310^{\circ} \mathrm{F}\right)$; a lubricant flow rate through the inner race, $L_{i}$, of $1.2 \times 10^{-3}$ cubic meters per minute $(0.313 \mathrm{gpm})$; an inner-race cooling rate, $c_{i}$, of $3.6 \times 10^{-3}$ cubic meters per minute $(0.94 \mathrm{gpm})$ or $3 \mathrm{~L}_{i}$; and an outer-race cooling flow rate, $C_{0}$, of $1.9 \times 10^{-3}$ cubic meters per minute $(0.5 \mathrm{gpm})$. Generally, throughout the range of speeds for the 6672- and 13345-N (1500- and 30001b) thrust loads, the bearing inner-race temperatures were 3 to $8 \mathrm{~K}$ ( 5 to 15 F) higher than the outer-race temperatures (Eigs, 5(a) and (b)). For the 22241-N (5000-1b) thrust load, the temperatures of the inner and outer races were generally within $3 \mathrm{~K}(5 \mathrm{~F})$ of each other. Over the range of speeds, the temperature of the bearing races increased from the range of 441 to $453 \mathrm{~K}\left(335^{\circ}\right.$ to $\left.355^{\circ} \mathrm{F}\right)$, to temperatures in the range of 478 to $494 \mathrm{~K}\left(400^{\circ}\right.$ to $\left.430^{\circ} \mathrm{F}\right)$ or an increase of approximately 36 to $42 \mathrm{~K}(65$ to $75 \mathrm{~F})$. In general, the $24^{\circ}$ contact angles bearings $\mathrm{ran}$ approximately 3 to $8 \mathrm{~K}(5$ to $10 \mathrm{~F})$ cooler than the $20^{\circ}$ contact angle bearings over the entire speed range. This difference in temperature was not considered significant.

The power loss for the bearings over the speed range is shown in figure 6. As would be expected, bearing power consumption increases linearly with speed for the three loads shown. At the thrust load of $22241 \mathrm{~N}(5000 \mathrm{lb})$ and a speed of $25000 \mathrm{rpm}$, the power loss is approximately $15 \mathrm{~kW}$ (20 horsepower) per beatig for the two contact angles. At the speed of $12000 \mathrm{rpm}$ and a thrust $10 \mathrm{ad}$ of $6672 \mathrm{~N}(1500 \mathrm{1b})$, the power loss is approximately $3 \mathrm{~kW}$ ( 4 horsepower) or 20 percent of the power loss at the high-speed, high-load condition. 
Comparing the power consumption of the two contact-angle bearings at the $22241 \mathrm{~N}(5000 \mathrm{lb})$ load and at low speeds, the $24^{\circ}$ contact-angle bearing had a power loss approximately 25 -percent greater than the $20^{\circ}$ contactangle bearing. At the higher speeds and for all three loads, the difference in power loss between the two contact angles was essentially Insignificant.

Another effect of speed on bearing operation is the centrifugal effect on outer-race load or stress and dynamic contact angle. The effect of speed on contact stress and operating contact angle using the methods of Harris $[10,11]$ are shown in Table 3. For these calculations, a bearing operating temperature of $478 \mathrm{~K}\left(400^{\circ} \mathrm{F}\right)$ was assumed. These calculated data show that there is a more marked increase in stress at the outer-race ball contact at the lower thrust 1oad of $6672 \mathrm{~N}(1500 \mathrm{lb})$ than at the $22241-\mathrm{N}(5000-1 \mathrm{~b})$ thrust load. This difference in the relative increase in stress at the outer-race ball contact, probably accounts for the slightly higher rate of increase in power consumption with speed with the lower thrust-loaded bearing tests. Contact-angle measurements were made on bearings having an initial contact angle of $24^{\circ}$ and tested at 12000,16000 , and $25000 \mathrm{rpm}$ at a load of $22241 \mathrm{~N}(4000 \mathrm{lb})$. The actual measurements were in excellent agreement with the prediction made in Table 3, with the exception of the inner-race contact angle at the maximum speed condition. Here the measured angle was approximately $25^{\circ}$ versus a predicted operating angle of $34^{\circ}$. The reason for this discrepancy is not understood at the present time. 
เ.

Effect of Load

The effect of load on the bearing temperature is shown in Fig. 7 . Bearing temperatures increased nearly linearly with load for most of the speeds. However, a temperature rise of only 6 to $11 \mathrm{~K}(10$ to $30 \mathrm{~F})$ occurs when the load was increased from 6672 to $22241 \mathrm{~N}$ (1500 to $50001 \mathrm{~b})$. The difference in temperature between the inner and outer race for the $24^{\circ}$ contact-angle bearings was insignificant and generally was within $\pm 3 \mathrm{~K}( \pm 5 \mathrm{~F})$. For the $20^{\circ}$ contact-angle bearings, the variation in temperature between the inner and outer races was slightly greater at the lower loads. This difference in temperature, however, did not exceed $8 \mathrm{~K}(15 \mathrm{~F})$. Bearing power loss as a function of load for the two contact angles is shown in figure 8. The greatest increase in power consumption at any speed was approximately $3 \mathrm{~kW}$ ( 4 horsepower) from the 6672-N (1500-1b) thrust load to the $22241-\mathrm{N}(5000-1 \mathrm{~b})$ thrust load. The increase in power consumption with thrust is considered negligible for most practical applications.

Effect of lubricant flow. - The effect of lubricant flow into the bearing, and that used for cooling of the inner and outer races was determined. A test condition was selected which incorporated a speed of $25000 \mathrm{rpm}$ ( 3 million DN) and a thrust load of $22241 \mathrm{~N}$ (5000 1b). This condition was chosen on the basis of approaching maximum Hertzian stresses $\left[2068 \times 10^{6} \mathrm{~N} / \mathrm{m}^{2}(\sim 300000 \mathrm{psi})\right]$ and speeds which can reasonably be anticipated in advanced state-of-the-art turbojet engines. Outerrace cooling flow $\left(C_{0}\right)$ was $9.5 \times 10^{-4}, 1.9 \times 10^{-3}, 3.8 \times 10^{-3}$, and $5.7 \times 10^{-3}$ cubic meters per minute $(0.25,0.5,1.0$, and $1.5 \mathrm{gpm})$. Inner-race 
lubricant flow $\left(\mathrm{L}_{i}\right)$ ranged from $7.6 \times 10^{-4}$ cubic meters per minute $(0.2$ gpm) to approximately $5.7 \times 10^{-3}$ cubic meters per minute (1.5 gpm). Inne:race cooling $\left(C_{i}\right)$ was varied as a function of $L_{i}$. The resita see tests are shown in Figs. 9 and 10.

Referring to Fig: $\quad 9(a)$, the test results are shown for the $20^{\circ}$ contact-angle bearing with no inner-race cooling flow $\left(C_{i}\right)$ except for that lubricant entering the inner race through the slots in the mating surfaces of the split inner race. The temperatures of the inner race varied generally from 6 to $11 \mathrm{~K}(10$ to $20 \mathrm{~F})$ for a particular lubricant flow $\left(\mathrm{L}_{i}\right)$ over the range of outer-race cooling rates $\left(\mathrm{C}_{\mathrm{o}}\right)$. At a lubricant flow $\left(\mathrm{L}_{i}\right)$ of approximately $2.3 \times 10^{-3}$ cubic meters per minute $(0.6 \mathrm{gpm})$ to the inner race, the temperature of this component ranged from approximately 486 to $497 \mathrm{~K}\left(415^{\circ}\right.$ to $\left.435^{\circ} \mathrm{F}\right)$ at an oil inlet temperperature of $394 \mathrm{~K}\left(250^{\circ} \mathrm{F}\right)$. The actual temperature defends upon the outerrace cooling flow $\left(\mathrm{C}_{0}\right)$. At an increased lubricant flow rate to the inner race $\left(\mathrm{L}_{i}\right)$ of approximately $4.5 \times 10^{-3}$ cubic meters per minute (1.2 $\mathrm{gpm})$, the temperature ranged from 472 to $475 \mathrm{~K}\left(390^{\circ}\right.$ to $\left.395^{\circ} \mathrm{F}\right)$.

At an outer-race cooling flow $\left(\mathrm{C}_{0}\right)$ of $9.5 \times 10^{-4}$ cubic meters per minute $(0.25 \mathrm{gpm})$ (fig. $9(\mathrm{a}))$, the temperature of the outer race was nearly equal to that of the inner race. As the flow rate to the outer race $\left(C_{0}\right)$ was increased, the outer-race temperature decreased. At an outer-race flow $\left(\mathrm{C}_{\mathrm{o}}\right)$ of $5.7 \times 10^{-3}$ cubic meters per minute $(1.5 \mathrm{gpm})$ the temperature of the outer race was approximately $17 \mathrm{~K}(30 \mathrm{~F})$ lower than the inner-race temperature. The amount of decrease in outer-race temperatures, with increasing inner race flow $\left(\mathrm{L}_{i}\right)$ for all values of $\mathrm{C}_{0}$, 
generally paralleled those of the inner race. What is significant is that the internal clearances of the bearing will be affected with the changes in the outer-race cooling flow $\left(\mathrm{C}_{\mathrm{o}}\right)$.

Referring to Fig. 9 (b) wherein the inner-race cooling flow rate $\left(C_{i}\right)$ was $1.33 \mathrm{~L}_{1}$, the temperature of the inner race ranged from $478 \mathrm{~K}$ $\left(400^{\circ} \mathrm{F}\right)$ at an inner-race lubricant flow rate $\left(\mathrm{L}_{i}\right)$ of $1.1 \times 10^{-3}$ cubic meters per minute $(0.3 \mathrm{gpm})$ to approximately $461 \mathrm{~K}\left(370^{\circ} \mathrm{F}\right)$ when the inner-race flow rate was doubled to $2.3 \times 10^{-3}$ cubic meters per minute (0.6 gpm). Beyond this value of $L_{i}$, the temperature of the inner race increased again.

In general, the outer-race temperature paralleled the inner-race temperature for the various outer-race cooling flow rates $\left(\mathrm{C}_{0}\right)$. However, the inner-race temperatures were not significantly affected by the outer-race flow rates $\left(\mathrm{C}_{0}\right)$. At an outer-race cooling flow $\left(\mathrm{C}_{0}\right)$ of $1.9 \times 10^{-3}$ cubic meters per minute $(0.5 \mathrm{gpm})$, the temperature of the inner and outer race was approximately equal (fig. 9(b)). However, at an $L_{i}$ value of $2.3 \times 10^{-3}$ cubic meters per minute $(0.6 \mathrm{gpm})$ and with inner-race cooling $\left(C_{i}\right)$, a decrease of as much as $36 \mathrm{~K}(55 \mathrm{~F})$ can be achieved over the same bearing having no lubricant cooling flow to the inner-race lands (Fig. 9(a)). It may be concluded, that inner-land cooling $\left(\mathrm{C}_{\mathbf{i}}\right)$ can play a significant role in reducing the detrimental thermal effects on the bearing and specifically under marginal lubrication conditions.

The data obtained with the $24^{\circ}$ contact-angle bearing and a value of $C_{i}=0$ are shown in Fig. $9(c)$. The results under this operating 
condition were generally similar to those obtained for the $20^{\circ}$ contact angle bearing shown in Fig. $9(a)$. However, the inner-race temperatures of the $24^{\circ}$ contact-angle bearing varied over a greater range. At a lubricant flow to the inner race $\left(L_{i}\right)$ of approximately $1.9 \times 10^{-3}$ cubic meters per minute $(0.5 \mathrm{gpm})$, the temperature ranged from approximately 478 to $494 \mathrm{~K}\left(400^{\circ}\right.$ to $\left.430^{\circ} \mathrm{F}\right)$ with various levels of outer-race cooling flow rate $\left(\mathrm{C}_{\mathrm{o}}\right)$. This temperature of the inner race decreased with increasing inner-race lubricant flow rate $\left(\mathrm{L}_{i}\right)$. At a value of $\mathrm{L}_{i}$ equal to $3.8 \times 10^{-3}$ cubic meters per minute ( $1 \mathrm{gpm}$ ), operating temperatures were at a minimum ranging between 464 to $479 \mathrm{~K}\left(375^{\circ}\right.$ to $\left.390^{\circ} \mathrm{F}\right)$. Beyond this flow rate temperatures began to increase as lubricant flow $\left(\mathrm{L}_{i}\right)$ increased. This rise in temperature was probably due to the increased quantity of lubricant within the bearing cavity and to the resultant churning effects. Again, the outer-race temperature closely paralleled the inner-race temouter-

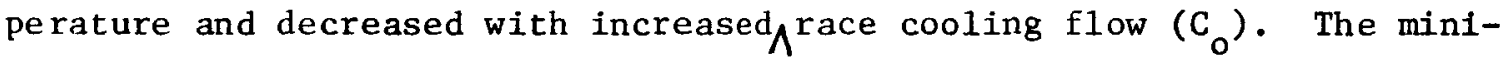
mum outer-race temperature, achieved with an outer-race cooling flow ( $C_{0}$ ) of $5.7 \times 10^{-3}$ cubic meters $(1.5 \mathrm{gpm})$, was approximately $455 \mathrm{~K}\left(360^{\circ} \mathrm{F}\right)$.

At an inner-race cooling flow of $C_{i}$ equal $1.33 \mathrm{~L}_{i}$ shown in Fig. $9(\mathrm{~d})$, the minimum inner-race temperature was approximately $458 \mathrm{~K}\left(365^{\circ} \mathrm{F}\right)$. The minimum temperature at the outer race was obtained at an outer-race cooling flow $\left(\mathrm{C}_{\mathrm{o}}\right)$ of $5.7 \times 10^{-3}$ cubic meters per minute $(1.5 \mathrm{gpm})$. This temperature was approximately $447 \mathrm{~K}\left(345^{\circ} \mathrm{F}\right)$. At a value of $\mathrm{L}_{\mathbf{i}}$ in excess of $1.5 \times 10^{-3}$ cubic meters per minute $(0.4 \mathrm{gpm})$, temperature at the inner race began to increase. Likewise, the temperatures at the outer race which parallel those of the inner race, except at an outer-race flow rate 
of $9.5 \times 10^{-4}$ cubic meters per minute $(0.25 \mathrm{gpm})$, began to increase. For a lubricant inner-race flow $C_{i}$ equal to $3.0 \mathrm{~L}_{1}$ (Fig. 9(e)) the range of component temperatures was very narrow, decreasing from $460 \mathrm{~K}\left(370^{\circ} \mathrm{F}\right)$ at a flow rate of $\mathrm{L}_{i}$ equal to $7.6 \times 10^{-4}$ cubic meters per minute $(0.2 \mathrm{gpm})$ to $350^{\circ} \mathrm{F}$ at $\mathrm{L}_{i}$ equal to $1.5 \times 10^{-3}$ cubic meters per minute $(0.4 \mathrm{gpm})$. Beyond this point, temperature rapidly increased at the inner race. The optimum matching of inner- to outer-race temperatures was obtained with outer-race lubricant cooling rates $\left(C_{o}\right)$ ranging between $3.8 \times 10^{-3}$ to $5.7 \times 10^{-3}$ cubic meters per minute ( 1 to $1.5 \mathrm{gpm}$ ).

A summary of the inner-race temperatures is shown in Fig. $9(f)$. From these data it may be concluded that the $24^{\circ}$ contact-angle bearing ran slightly cooler than its $20^{\circ}$ contact-angle equivalent. However, this difference in temperature was only about $8 \mathrm{~K}(15 \mathrm{~F})$ over most of the comparable operating conditions. As the inner-race cooling flow $\left(C_{i}\right)$ increased, temperatures decreased significantly. The maximum difference in temperature $50 \mathrm{~K}(90 \mathrm{~F})$ was observed between $C_{i}$ equal to $3.0 \mathrm{~L}_{i}$ and $\mathrm{C}_{i}$ equals zero. In the case where no cooling was attempted of the inner race except for that provided by the inner-race lubricant flow $\left(L_{i}\right)$, most of this difference can be accounted for by the fact that a major cause of the heat generation within the bearing is likely due to churning of the lubricant within the bearing cavity.

Power loss as a function of inner-race cooling $\left(C_{i}\right)$ and lubrication $\left(L_{i}\right)$ is presented in Fig. 10. The power loss increases linearly with increased flow to the inner race. For outer-race cooling flows from $9.5 \times 10^{-4}$ to $3.8 \times 10^{-3}$ cubic meters per minute $(0.25$ to $1.0 \mathrm{gpm})$ there was 
essentially no significant difference in power loss. At an outer-race cooling flow $\left(\mathrm{C}_{0}\right)$ of $5.7 \times 10^{-3}$ cubic meters per minute $(1.5 \mathrm{gpm})$ the power loss was approximately 0.75 to $3 \mathrm{~kW}$ ( 1 to 4 horsepower) greater than at the lower values of $C_{0}$. This difference in power consumption can be attributed to the reduction in bearing internal clearances due to temperature differences between the inner and outer races. The rate of increase in power loss with $\mathrm{L}_{i}$ is due to both the amount of oil used for the inner-race cooling flow $\left(C_{i}\right)$ and that used for the primary lubricant flow, $\mathrm{L}_{i}$.

The rapid increase in power consumption with increased $C_{i}$ can be attributed to a larger quantity of lubricant being entrapped within the bearing cavity at the higher lubricant flow rates. For all values of $C_{0}$, the extrapolated value of power loss where $L_{i}$ was zero was in the range of 9 to $12 \mathrm{~kW}$ (12 to 16 horsepower).

Referring to Fig. 10 (f) which is a summary of the range of power loss for the $20^{\circ}$ and $24^{\circ}$ contact angles, there appears to be no significant difference between the power loss with either of these contact angles for a particular inner-race cooling flow $\left(C_{i}\right)$. This is expected since power loss increases when the amount and viscosity of o11 within the bearing cavity is increased. It must be recognized, however, that al1 power loss data presented herein are based solely on shaft horsepower measurements. As such, they do not necessarily encompass the power requirement for pumping the lubricant, and, more specifically, for circulating the oil used to cool the outer race. 
The above results indicate that the bearing can be temperature and power tuned to any specific operating condition depending upon the lubricant characteristics. The concept of Bearing Thermal Management proposed herein, is believed to be the proper technological approach to high-speed bearing operation. The basis of this is the recognition that total and flexible thermal control over all of the bearing components is essential to achieve a reliable high-speed, highly-loaded bearing. This in turn requires a lubrication scheme of sufficient sophistication to achieve the thermal controls and still permit its practical use in actual flight hardware.

Bearing endurance at 3 million DN. - Preliminary bearing endurance tests were conducted with the $24^{\circ}$ contact-angle bearing at a speed of $25000 \mathrm{rpm}$ ( 3 million DN) and a thrust load of $22241 \mathrm{~N}(5000 \mathrm{lb})$. Under these conditions the maximum Hertz stresses in the inner and outer races are $1965 \times 10^{6}$ and $2096 \times 10^{6} \mathrm{~N} / \mathrm{m}^{2}$ (285 000 and 304000 psi), respectively. For these long-time, high-speed bearing tests the cooling-flow rate per bearing to the outer race $\left(C_{0}\right)$ was $2.8 \times 10^{-3}$ cubic meters per minute $(0.75 \mathrm{gpm})$. Lubricant flow to the inner race $\left(\mathrm{L}_{i}\right)$ was $1.3 \times 10^{-3}$ cubic meters per minute $(0.35 \mathrm{gpm})$ and inner-race cooling flow $\left(C_{i}\right)$ was approx-

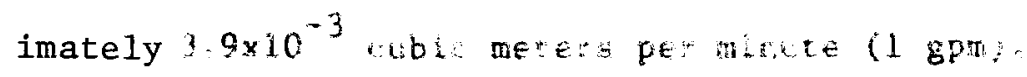

The standard AFBMA (catalog)-1ife calculation predicts a bearing ten-percent $\left(B_{10}\right)$ life under these operating conditions of approximately 16 hours. (The bearing 10-percent $\left(B_{10}\right)$ life is the operating time (1ife) at which $90 \%$ of a group of bearings will survive.) However, using the material, lubricant and speed factors given in [17] a $B_{10}$ 1ife 
of about 175 hours would be a more reasonable prediction. Of the ten bearings initially tested all ran for 1000 hours without failure. These results show that long-term bearing operation at 3 million DN can be achieved with a high degree of reliability using sophisticated but currently available state-of-the-art bearing materials and designs, 1ubricants, and Iubrication techniques.

\section{SUMMARY}

A parametric study was performed with $120-\mathrm{mm}$ bore angular-contact ball bearings having nominal $20^{\circ}$ and $24^{\circ}$ contact angles under varying thrust load, bearing and lubricant temperature, and cooling and lubricant flow rates at speeds to 3 million DN. Endurance tests were run at 3 million DN and a temperature of $492 \mathrm{~K}\left(425^{\circ} \mathrm{F}\right)$ with 10 bearings having a nominal $24^{\circ}$ contact angle at a thrust load of $22241 \mathrm{~N}$ (5000 1b) producing a maximum Hertz stress of $1965 \times 10^{6}$ and $2096 \times 10^{6} \mathrm{~N} / \mathrm{m}^{2}(285000$ and $304000 \mathrm{psi}$ ) on the bearing inner and outer races, respectively. The following results were obtained:

1. Bearing inner- and outer-race temperatures and power consumption were found to vary with load, speed, lubricant flow rate into the bearing, and lubricant cooling to the inner race. Lubricant cooling flow to the outer race was found to affect outer-race temperatures significantly, but had only a small effect on the measured inner-race temperature. Power loss due to change in lubricant cooling flow to the outer race was relatively insignificant.

2. Bearing operating temperature, differences in temperatures between the inner and outer races, and bearing power consumption can be 
tuned to any desirable operating requirement by varying 4 parameters. These parameters are outer-race cooling, inner-race cooling, lubricant flow to the inner race and oil inlet temperature.

3. All ten bearings which were endurance tested $r$ an for times in excess of 1000 hours without failure. These results indicate that long-term bearing operation at 3 million DN can be achieved with a high degree of reliability using sophisticated but currently available stateof-the-art bearing materials, designs, lubricants, and lubrication techniques. 


\section{REFERENCES}

1. Bamberger, E. N., Zaretsky, E. V., and Anderson, W. J., "Fatigue Life of 120-mm Bore Ball Bearings at $600^{\circ} \mathrm{F}$ with Fluorocarbon, Polyphenyl Ether and Synthetic Paraffinic Base Lubricants", NASA TN D-4850, 1968.

2. Bamberger, E. N., Zaretsky, E. V., and Anderson, W. J., "Effect of Three Advanced Lubricants on High Temperature Bearing Life", Journal of Lubrication Technology, Trans. ASME, Series F, Vol. 92, No. 1, 1970, pp. 23-33.

3. Zaretsky, E. V., and Bamberger, E. N., "Advanced Airbreathing Engine Lubricants Study with a Tetraester Fluid and a Synthetic Paraffinic 0 il at $492 \mathrm{~K}\left(425^{\circ} \mathrm{F}\right) "$, NASA TN D-6771, 1972.

4. Parker, R. J., and Zaretsky, E. V., "Effect of Oxygen Concentration on an Advanced Ester Lubricant in Bearing Tests at $400^{\circ}$ and $450^{\circ}$ F", NASA TN D-5269, 1969.

5. D'Orazio, A. J., "Development and Utilization of Specification Mil-L23699 - Synthetic Lubricating 0ils for Aircraft Gas Turbine Engines", U.S. Navy NAPTC-AED-1868, 1968.

6. Parker, R. J., and Zaretsky, E. V., "Rolling Element Fatigue Lives of Through-Hardened Bearing Materials", Journal of Lubrication Technology, Trans. ASME, Series F, Vol. 94, No. 2, 1972, pp. 155-173.

7. Jones, A. B., "The Life of High Speed Ball Bearings", Trans. ASME, Vol. 74, No. 5, 1952, pp. 695-703.

8. Jones, A. B., "Ball Motion and Sliding Friction on Ba11 Bearings", Journal of Basic Engineering, Trans. ASME, Series D, Vol. 81, No. 1, 1959, pp. 1-12. 
9. Jones, A. B., "A General Theory for Elastically Constrained Ball and Roller Bearings under Arbitrary Load and Speed Conditions", Journal of Basic Engineering, Trans. ASME, Series D, Vo1. 82, No. 2, 1960, pp. 309-320.

10. Harris, T. A., "An Analytical Method to Predict Skidding in Thrust Loaded, Angular Contact Ball Bearings", Journal of Lubrication Technology, Trans. ASME, Series F, Vo1. 93, No. 1, 1971, Pp. 17-24.

11. Harris, T. A., "An Analytical Method to Predict Skidding in High Speed Roller Bearings", ASLE Transactions, Vol. 9, No. 3, 1966, pp. 229-241.

12. Scibbe, H. W., and Zaretsky, E. V., "Advanced Design Concepts for High Speed Bearings", ASME Paper 71-DE-50, 1971.

13. Holmes, P. W., "Evaluation of Drilled Ball Bearings at DN Values to Three Million", NASA CR-2004, NASA CR-2005, 1972.

14. Zaretsky, E. V., Bamberger, E. N., and Signer, H., "Operating Characteristics of 120-mm Bore Ball Bearings at $3 \times 10^{6} \mathrm{DN}$ ", Proposed NASA Technical Note, 1974.

15. Bamberger, E. N., Zaretsky, E. V., and Signer, H., "Effect of Speed and Load on Ultra High Speed Ball Bearings", Proposed NASA Technical Note, 1974 .

16. Zaretsky, E. V., Parker, R. J., Anderson, W. J., and Reichard, D. W., "Bearing Life and Failure Distribution as Affected by Actual Component Differential Hardness", NASA TN D-3101, 1965.

17. Bamberger, E. N., et al., "Life Adjustment Factors for Ball and Roller Bearings, An Engineering Design Guide", ASME, 1971. 
TABLE 1 - CHEMICAL ANALYSIS OF VACUUM INDUCTION, CONSUMABLEELECTRODE VACUUM REMELTED AISI M-50 BEARING STEEL

\begin{tabular}{|l|c|}
\hline \multirow{2}{*}{ Element } & Composition, wt. \% \\
\cline { 2 - 2 } Carbon & Races and Balls \\
Manganese & 0.83 \\
Phosphorus & .29 \\
Sulfur & .007 \\
Silicon & .005 \\
Chromium & .25 \\
Molybdenum & 4.11 \\
Vanadium & 4.32 \\
Iron & .98 \\
\hline
\end{tabular}


TABLE 2 - PROPERTIES OF TETRAESTER LUBRICANT

\begin{tabular}{|c|c|}
\hline Additives & $\begin{array}{l}\text { Antiwear } \\
\text { Oxidation Inhibitor } \\
\text { Antifoam }\end{array}$ \\
\hline Kinematic viscosity, $c S$, at - & \\
\hline $311 \mathrm{~K}\left(100^{\circ} \mathrm{F}\right)$ & 28.5 \\
\hline $372 \mathrm{~K}\left(210^{\circ} \mathrm{F}\right)$ & 5.22 \\
\hline $477 \mathrm{~K}\left(400^{\circ} \mathrm{F}\right)$ & 1.31 \\
\hline Flash point, $\mathrm{K}\left({ }^{\mathrm{o}} \mathrm{F}\right)$ & $533(500)$ \\
\hline Fire point, $\mathrm{K}\left({ }^{\mathrm{O}} \mathrm{F}\right)$ & Unknown \\
\hline Autoignition temperature, $\mathrm{K}\left({ }^{\mathrm{O}} \mathrm{F}\right)$ & $694(800)$ \\
\hline Pour point, $\mathrm{K}\left({ }^{\circ} \mathrm{F}\right)$ & $214(-75)$ \\
\hline $\begin{array}{l}\text { Volatility }(6.5 \mathrm{hr} \text { at } 477 \mathrm{~K} \\
\left.\left(400^{\circ} \mathrm{F}\right)\right) \text {, wt. } \%\end{array}$ & 3.2 \\
\hline $\begin{array}{l}\text { Specific heat at } 477 \mathrm{~K}\left(400^{\circ} \mathrm{F}\right) \text {, } \\
\mathrm{J} /(\mathrm{kg})(\mathrm{K})\left(\mathrm{Btu} /(1 \mathrm{~b})\left({ }^{\circ} \mathrm{F}\right)\right)\end{array}$ & $2340(0.54)$ \\
\hline $\begin{array}{l}\text { Thermal conductivity at } 477 \mathrm{~K} \\
\qquad\left(400^{\circ} \mathrm{F}\right), \mathrm{J} /(\mathrm{m})(\mathrm{sec})(\mathrm{K}) \\
\left(\mathrm{Btu} /(\mathrm{hr})(\mathrm{ft})\left({ }^{\circ} \mathrm{F}\right)\right)\end{array}$ & $0.13(0.075)$ \\
\hline Specific gravity at $477 \mathrm{~K}\left(400^{\circ} \mathrm{F}\right)$ & 0.850 \\
\hline
\end{tabular}


TABLE 3 - CALCULATED OPERATING CONTACT ANGLES AND STRESSES AS A FUNCTION OF INITIAL CONTACT ANGLE, SPEED AND LOAD

\begin{tabular}{|c|c|c|c|c|c|c|}
\hline \multirow{3}{*}{$\begin{array}{l}\text { Speed, } \\
\text { rpm }\end{array}$} & \multirow{3}{*}{$\begin{array}{l}\text { Thrust } \\
\text { load, } \\
\text { N (1b) }\end{array}$} & \multicolumn{3}{|c|}{ Contact angle, deg } & \multirow{2}{*}{\multicolumn{2}{|c|}{$\begin{array}{c}\text { Maximum Hertz } \\
\text { stress, } \mathrm{N} / \mathrm{m}^{2} \text { (ksi) }\end{array}$}} \\
\hline & & \multirow[t]{2}{*}{ Unloaded } & \multicolumn{2}{|c|}{ Operating } & & \\
\hline & & & Outer race & Inner race & race & race \\
\hline \multirow[t]{6}{*}{12000} & $\begin{array}{c}6672 \\
(1500)\end{array}$ & \multirow[t]{3}{*}{20} & 13 & 26 & $\begin{array}{l}1365 \times 10^{6} \\
(198)\end{array}$ & $\begin{array}{l}1420 \times 10^{6} \\
(206)\end{array}$ \\
\hline & $\begin{array}{l}13345 \\
(3000)\end{array}$ & & 18 & 26 & $\begin{array}{l}1572 \\
(228)\end{array}$ & $\begin{array}{l}1806 \\
(262)\end{array}$ \\
\hline & $\begin{array}{l}22241 \\
(5000)\end{array}$ & & 27 & 27 & $\begin{array}{l}1779 \\
(258)\end{array}$ & $\begin{array}{l}2130 \\
(309)\end{array}$ \\
\hline & $\begin{array}{c}6672 \\
(1500)\end{array}$ & \multirow[t]{3}{*}{24} & 14 & 30 & $\begin{array}{l}1344 \\
(195)\end{array}$ & $\begin{array}{l}1351 \\
(196)\end{array}$ \\
\hline & $\begin{array}{c}3345 \\
(3000)\end{array}$ & & 19 & 30 & $\begin{array}{l}1531 \\
(222)\end{array}$ & $\begin{array}{l}1731 \\
(251)\end{array}$ \\
\hline & $\begin{array}{l}22241 \\
(5000)\end{array}$ & & 23 & 31 & $\begin{array}{l}1731 \\
(251)\end{array}$ & $\begin{array}{l}2048 \\
(297)\end{array}$ \\
\hline \multirow[t]{6}{*}{16000} & $\begin{array}{c}6672 \\
(1500)\end{array}$ & \multirow[t]{6}{*}{20} & 9 & 27 & $\begin{array}{l}1517 \times 10^{6} \\
(220)\end{array}$ & $\begin{array}{l}1400 \times 10^{6} \\
(203)\end{array}$ \\
\hline & $\begin{array}{c}3345 \\
(3000)\end{array}$ & & 14 & 28 & $\begin{array}{l}1682 \\
(244)\end{array}$ & $\begin{array}{l}1779 \\
(258)\end{array}$ \\
\hline & $\begin{array}{l}22241 \\
(5000)\end{array}$ & & 18 & 28 & $\begin{array}{l}1855 \\
(269)\end{array}$ & $\begin{array}{l}2096 \\
(304)\end{array}$ \\
\hline & $\begin{array}{c}6672 \\
(1500)\end{array}$ & & 9 & 32 & $\begin{array}{l}1503 \\
(218)\end{array}$ & $\begin{array}{l}1330 \\
(193)\end{array}$ \\
\hline & $\begin{array}{c}3345 \\
(3000)\end{array}$ & & 15 & 32 & $\begin{array}{l}1648 \\
(239)\end{array}$ & $\begin{array}{l}1703 \\
(247)\end{array}$ \\
\hline & $\begin{array}{l}22241 \\
(5000)\end{array}$ & & 19 & 32 & $\begin{array}{l}1813 \\
(263)\end{array}$ & $\begin{array}{l}2020 \\
(293)\end{array}$ \\
\hline \multirow[t]{6}{*}{20000} & $\begin{array}{c}6672 \\
(1500)\end{array}$ & \multirow[t]{3}{*}{20} & 6 & 28 & $\begin{array}{l}1682 \times 10^{6} \\
(244)\end{array}$ & $\begin{array}{l}1386 \times 10^{6} \\
(201)\end{array}$ \\
\hline & $\begin{array}{c}3345 \\
(3000)\end{array}$ & & 11 & 29 & $\begin{array}{l}1813 \\
(263)\end{array}$ & $\begin{array}{l}1758 \\
(255)\end{array}$ \\
\hline & $\begin{array}{l}22241 \\
(5000)\end{array}$ & & 15 & 29 & $\begin{array}{l}1958 \\
(284)\end{array}$ & $\begin{array}{l}2068 \\
(300)\end{array}$ \\
\hline & $\begin{array}{c}6672 \\
(1500)\end{array}$ & \multirow[t]{3}{*}{24} & 6 & 33 & $\begin{array}{l}1682 \\
(244)\end{array}$ & $\begin{array}{l}1324 \\
(192)\end{array}$ \\
\hline & $\begin{array}{c}3345 \\
(3000)\end{array}$ & & 12 & 33 & $\begin{array}{l}1923 \\
(260)\end{array}$ & $\begin{array}{l}1682 \\
(244)\end{array}$ \\
\hline & $\begin{array}{l}22241 \\
(5000)\end{array}$ & & 16 & 33 & $\begin{array}{l}1924 \\
(279)\end{array}$ & $\begin{array}{l}1993 \\
(289)\end{array}$ \\
\hline \multirow[t]{6}{*}{25000} & $\begin{array}{c}6672 \\
(1500)\end{array}$ & \multirow[t]{6}{*}{20} & 5 & 29 & $\begin{array}{l}1889 \times 10^{6} \\
(274)\end{array}$ & $\begin{array}{l}1365 \times 10^{6} \\
(198)\end{array}$ \\
\hline & $\begin{array}{c}3345 \\
(3000)\end{array}$ & & 8 & 30 & $\begin{array}{l}1993 \\
(289)\end{array}$ & $\begin{array}{l}1731 \\
(251)\end{array}$ \\
\hline & $\begin{array}{l}22241 \\
(5000)\end{array}$ & & 12 & 30 & $\begin{array}{l}2110 \\
(306)\end{array}$ & $\begin{array}{l}2041 \\
(296)\end{array}$ \\
\hline & $\begin{array}{c}6672 \\
(1500)\end{array}$ & & 5 & 34 & $\begin{array}{l}1862 \\
(270)\end{array}$ & $\begin{array}{l}1310 \\
(190)\end{array}$ \\
\hline & $\begin{array}{c}3345 \\
(3000)\end{array}$ & & 8 & 34 & $\begin{array}{l}1993 \\
(289)\end{array}$ & $\begin{array}{l}1662 \\
(241)\end{array}$ \\
\hline & $\begin{array}{l}22241 \\
(5000)\end{array}$ & & 12 & 34 & $\begin{array}{l}2096 \\
(304)\end{array}$ & $\begin{array}{l}1965 \\
(285)\end{array}$ \\
\hline
\end{tabular}




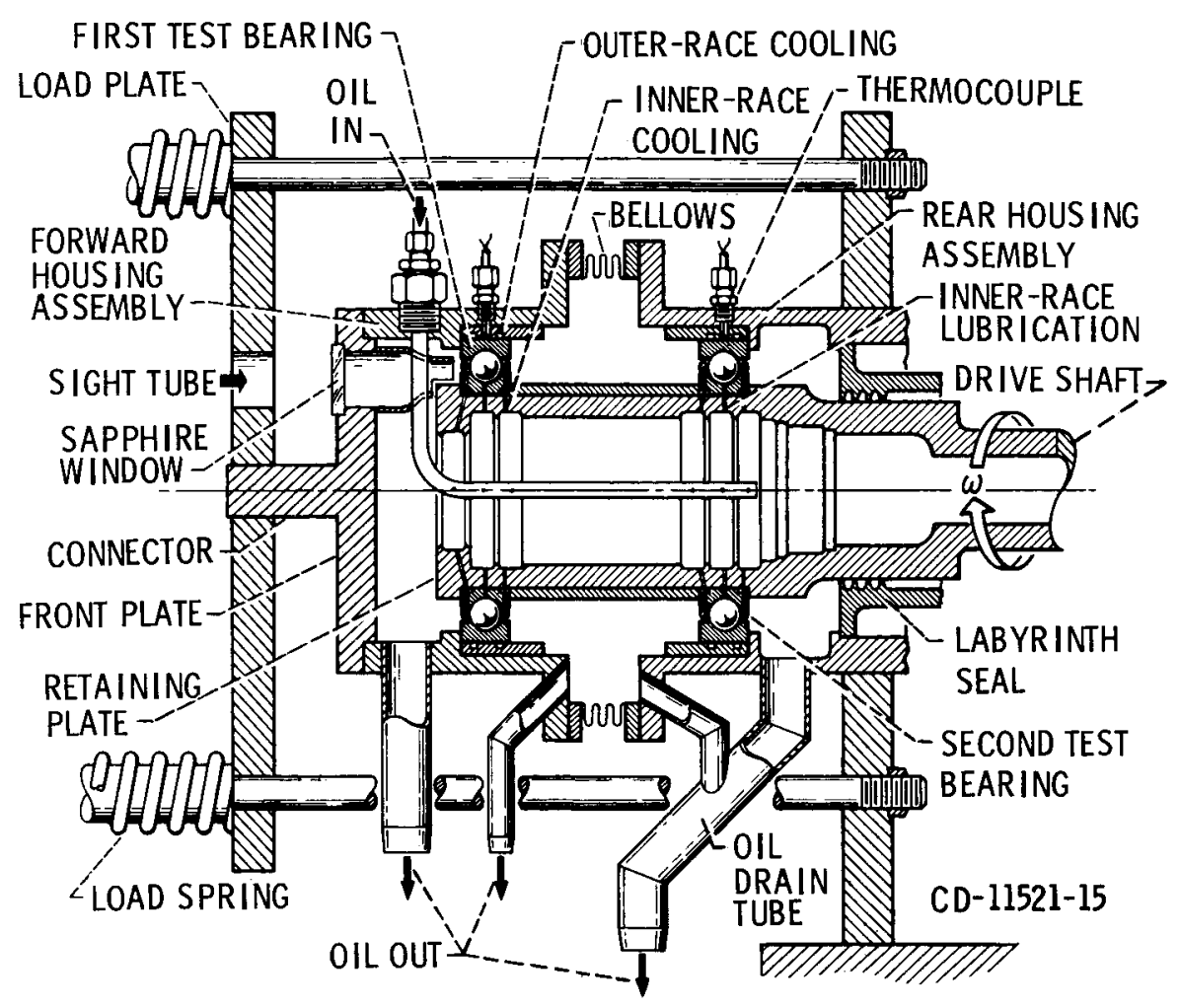

Fig. 1 High-speed, high-temperature bearing test apparatus.

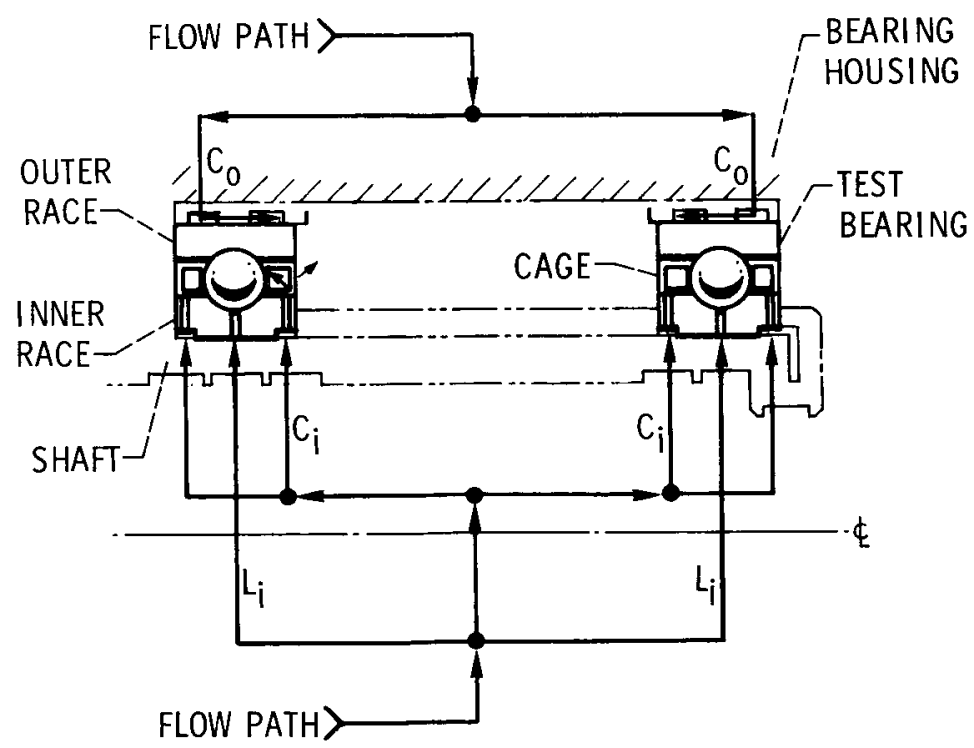

Fig. 2 Lubricant system for test bearings. 


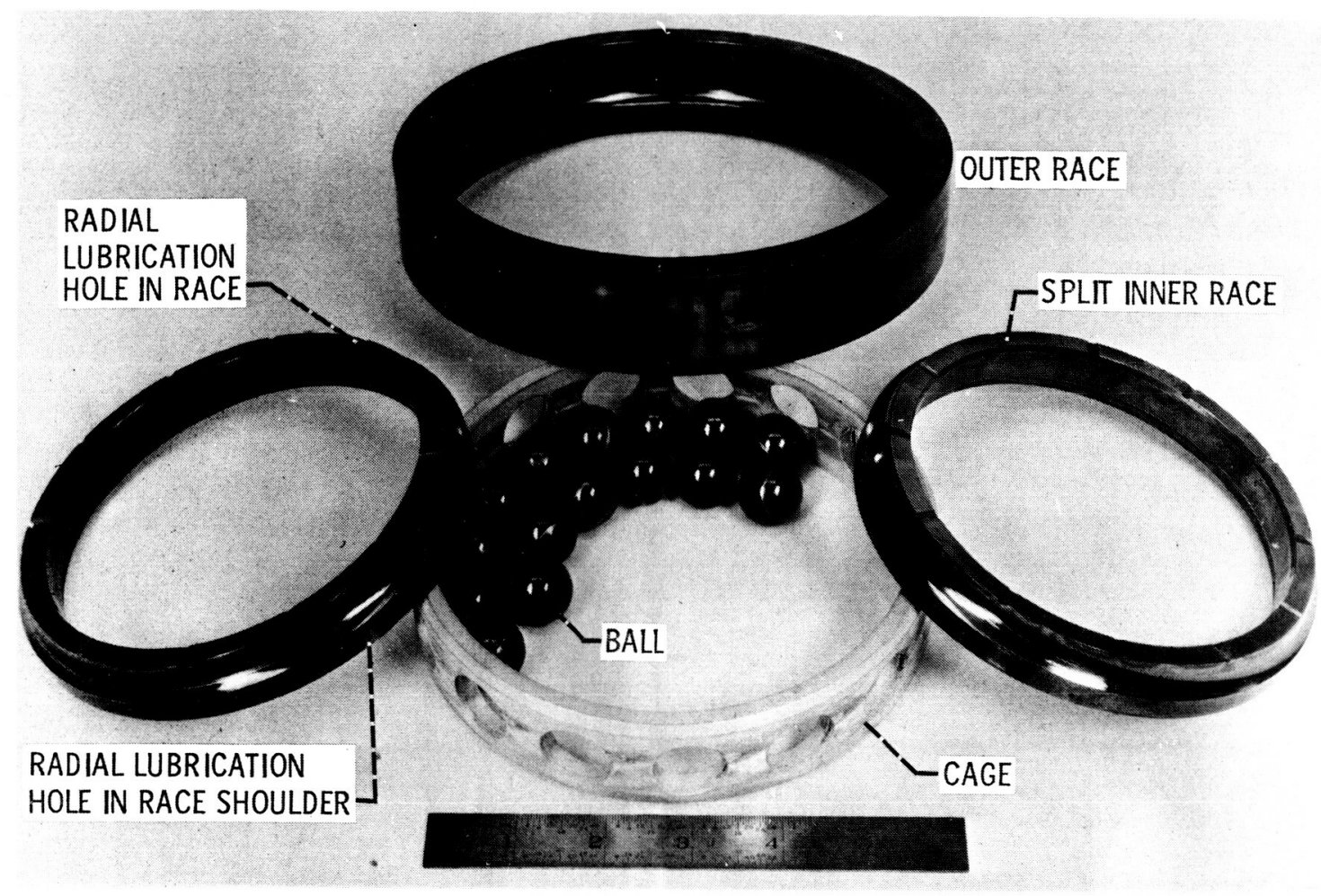

Fig. 3 Unfailed 120-mm bore angular-contact high-speed test ball bearing. Running time, 1000 hours; speed, $25000 \mathrm{rpm}$ (3 million DN); temperature, $492 \mathrm{~K}\left(425^{\circ} \mathrm{F}\right)$; thrust load, $22241 \mathrm{~N}(5000 \mathrm{lb})$.

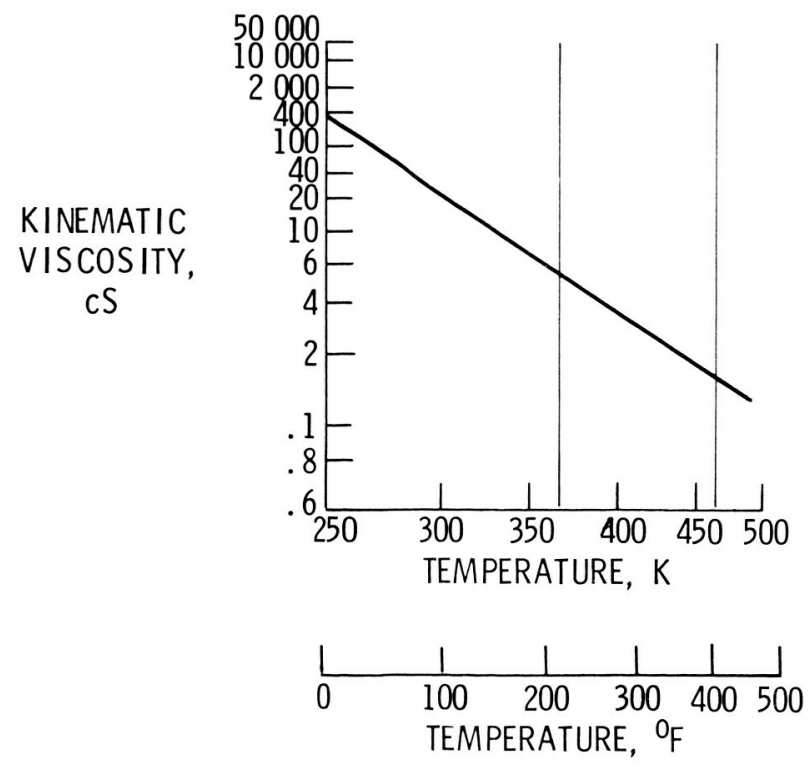

Fig. 4 Viscosity as function of temperature for tetra-ester (Type II) lubricant. 


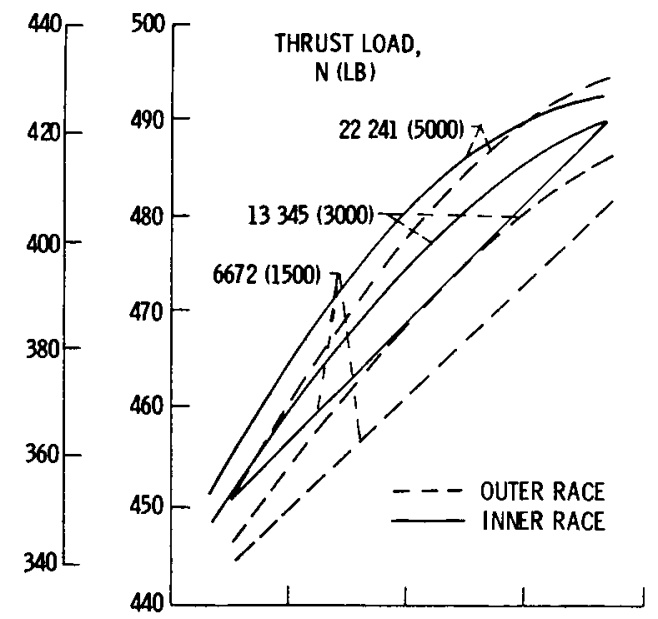

(a) CONTACT ANGLE, $20^{\circ}$.

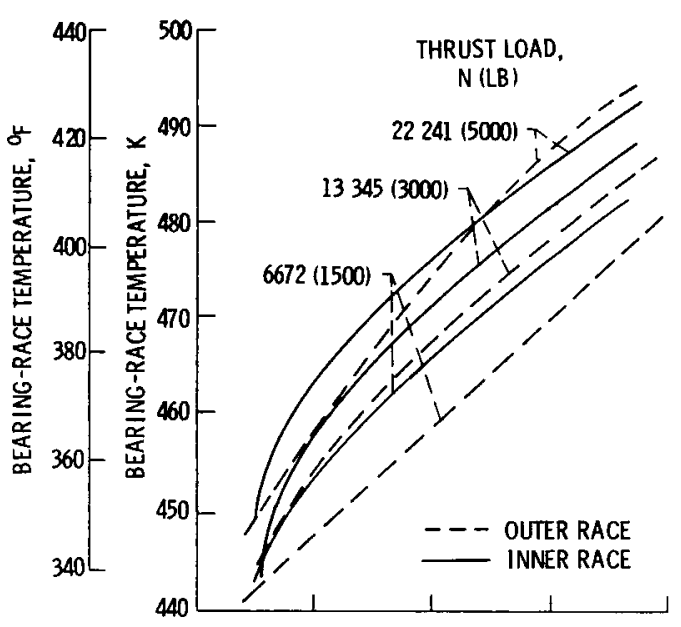

(b) CONTACT ANGLE, $24^{\circ}$.

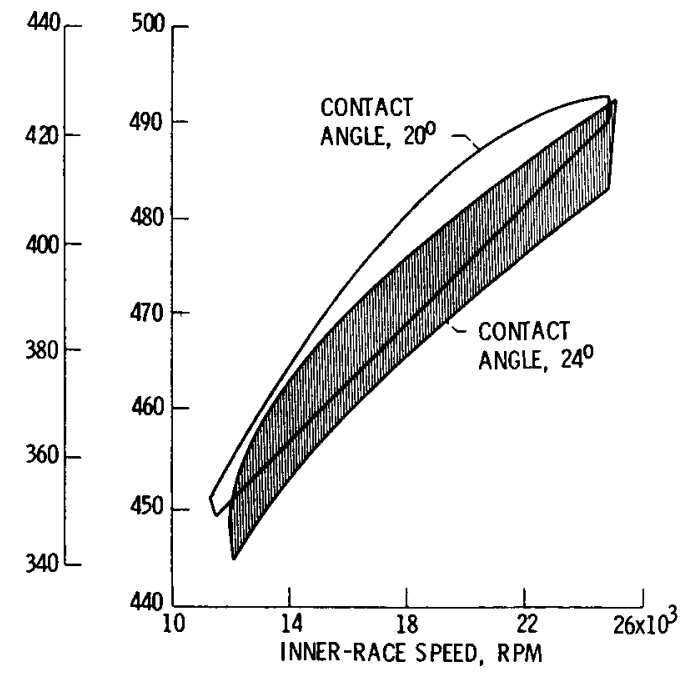

(c) SUMMARY OF INNER-RACE TEMPERATURE RANGE.

Fig. 5 Range of bearing race temperature as a function of speed for various thrust loads. Bearing type, $120-\mathrm{mm}$ bore angular-contact ball bearing; lubricant flow to inner race, $L_{i}, 1.2 \times 10^{-3} \mathrm{~m}^{3} / \min (0.313 \mathrm{gpm})$; inner-race cooling flow, $\mathrm{C}_{\mathrm{i}}, 3.6 \times 10^{-3} \mathrm{~m}^{3} / \mathrm{min}(0.94 \mathrm{gpm})$; outer-race cooling flow, $C_{0}, 1.9 \times 10^{-3} \mathrm{~m}^{3} / \mathrm{min}(0.5 \mathrm{gpm})$; oil inlet temperature, $428 \mathrm{~K}\left(310^{\circ} \mathrm{F}\right)$.

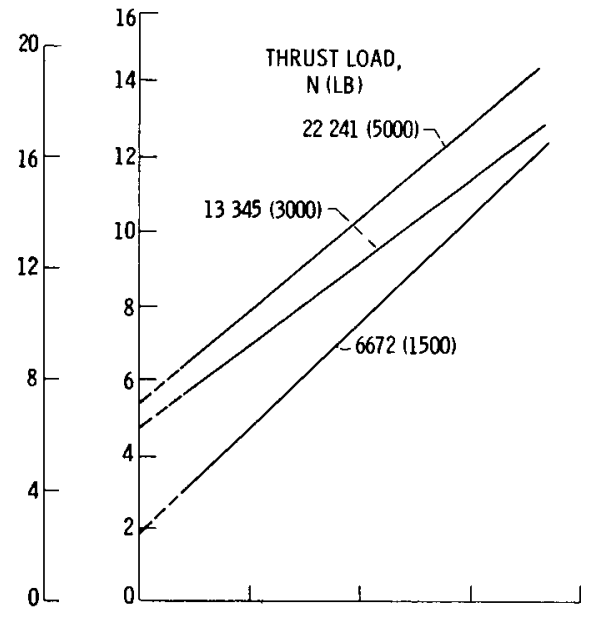

(a) CONTACT ANGLE, $20^{\circ}$.

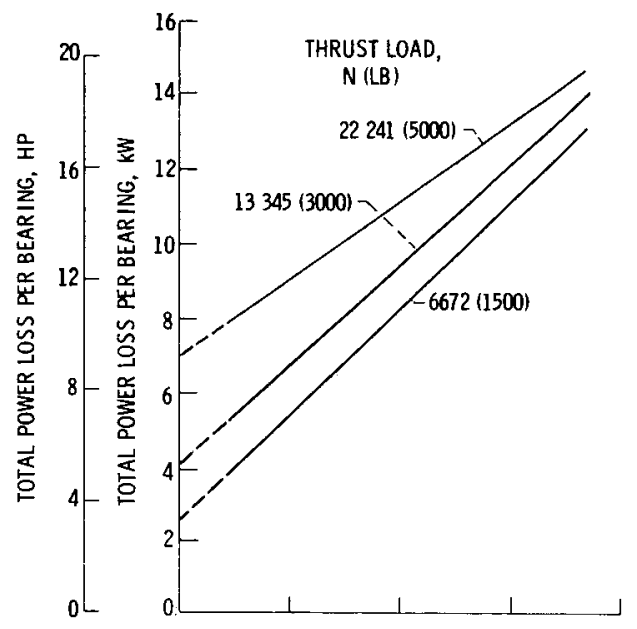

(b) CONTACT ANGLE, $24^{\circ}$

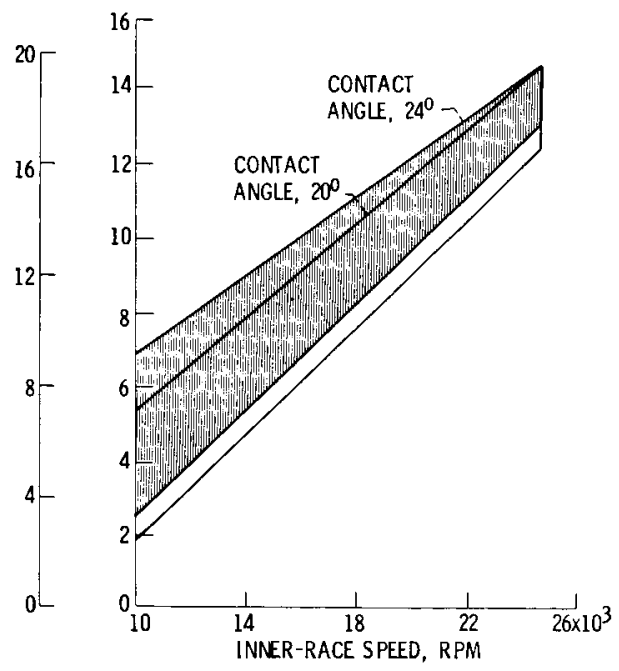

(c) SUMMARY.

Fig. 6 Range of power loss as a function of speed for varying thrust loads. Bearing type, $120-\mathrm{mm}$ bore angular-contact ball bearing; lubricant flow to inner race, $L_{i}, 1.2 \times 10^{-3} \mathrm{~m}^{3} / \mathrm{min}(0.313 \mathrm{gpm})$; inner-race cooling flow, $C_{j}, 3.6 \times 10^{-3} \mathrm{~m}^{3} / \mathrm{min}(0.94 \mathrm{gpm})$; outerrace cooling flow, $C, 1.9 \times 10^{-3} / \mathrm{min}(0.5 \mathrm{gpm})$; oil inlet temperature, $428 \mathrm{~K}\left(310^{\circ} \mathrm{F}\right)$. 

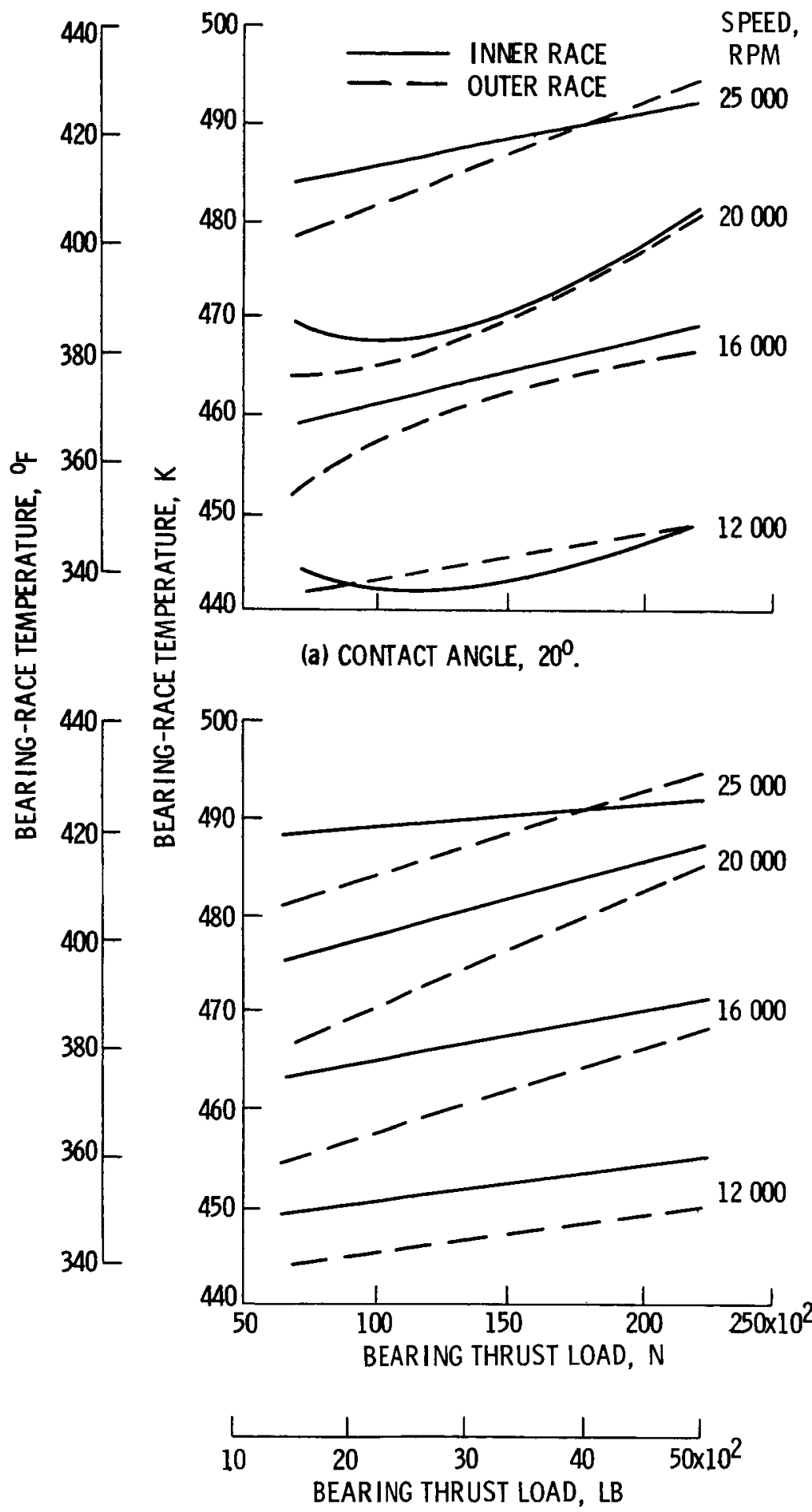

(b) CONTACT ANGLE, $24^{\circ}$.

Fig. 7 Range of bearing race temperature as a function of bearing thrust load for various speeds. Bearing type, 120-mm bore angular-contact ball bearing; lubricant flow to inner race, $L_{i}, 1.2 \times 10^{-3} \mathrm{~m}^{3} / \mathrm{min}(0.313 \mathrm{gpm})$; inner-race cooling flow, $C_{i}, 3.6 \times 10^{-3} \mathrm{~m}^{3} / \mathrm{min}(0.94 \mathrm{gpm})$; outer-race cooling flow, $\mathrm{C}_{0}, 1.9 \times 10^{-3} \mathrm{~m}^{3} / \mathrm{min}(0.5 \mathrm{gpm})$; oil inlet temperature, $428 \mathrm{~K}$ $\left(310^{\circ} \mathrm{F}\right)$. 

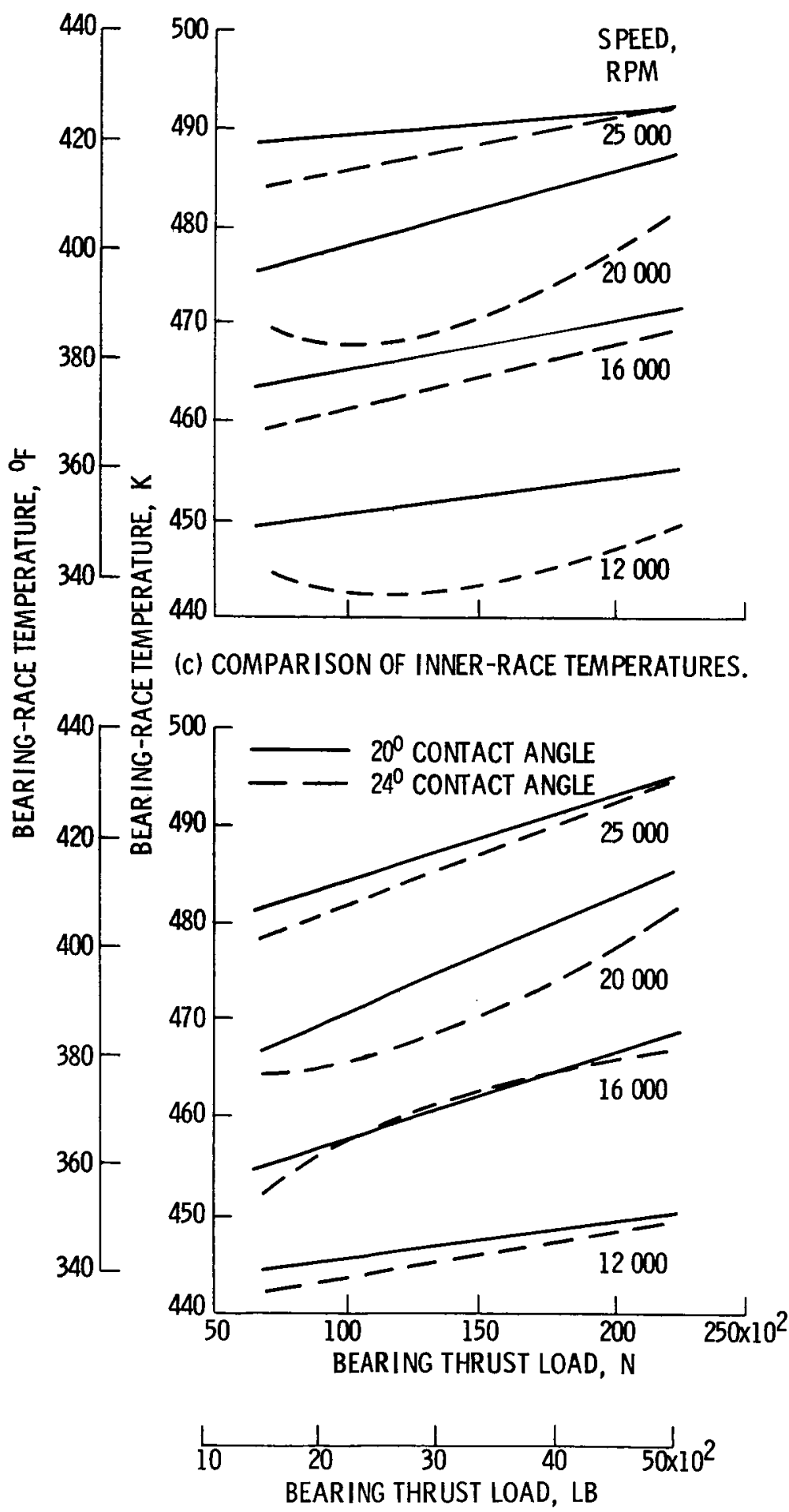

(d) COMPARISON OF OUTER-RACE TEMPERATURES.

Fig. 7 Concluded. 

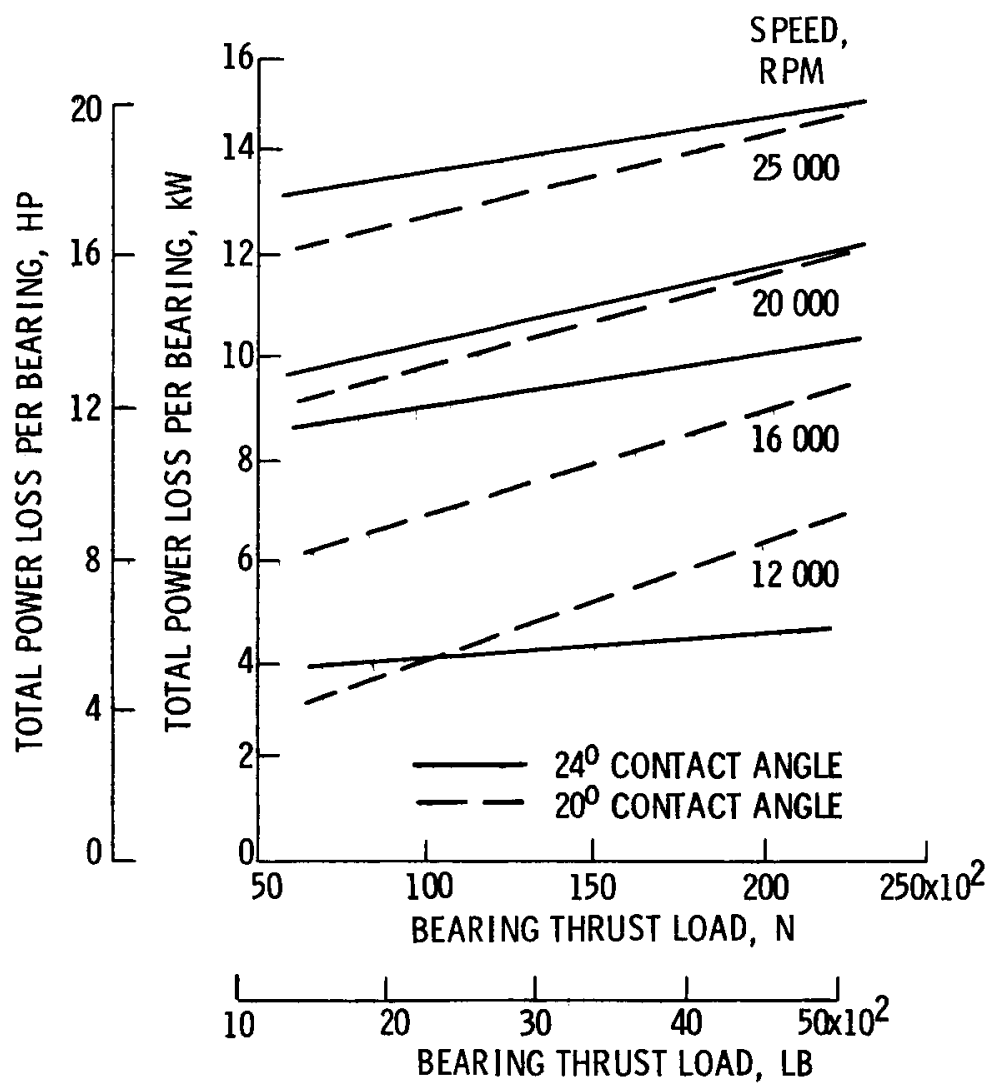

Fig. 8 Bearing power loss as a function of bearing thrust load for various speeds. Bearing type, 120-mm bore angular-contact ball bearing; lubricant flow to inner race, $L_{j}, 1.2 \times 10^{3} \mathrm{~m}^{3} / \mathrm{min}(0.313 \mathrm{gpm})$; innerrace cooling flow, $C_{i}, 3.6 \times 10^{-3} \mathrm{~m}^{3} / \mathrm{min}(0.94 \mathrm{gpm})$; outer-race cooling flow, $C_{0}, 1.9 \times 10^{-3} \mathrm{~m}^{3} / \mathrm{min}(0.5 \mathrm{gpm})$; oil inlet temperature, $428 \mathrm{~K}\left(310^{\circ} \mathrm{F}\right)$. 

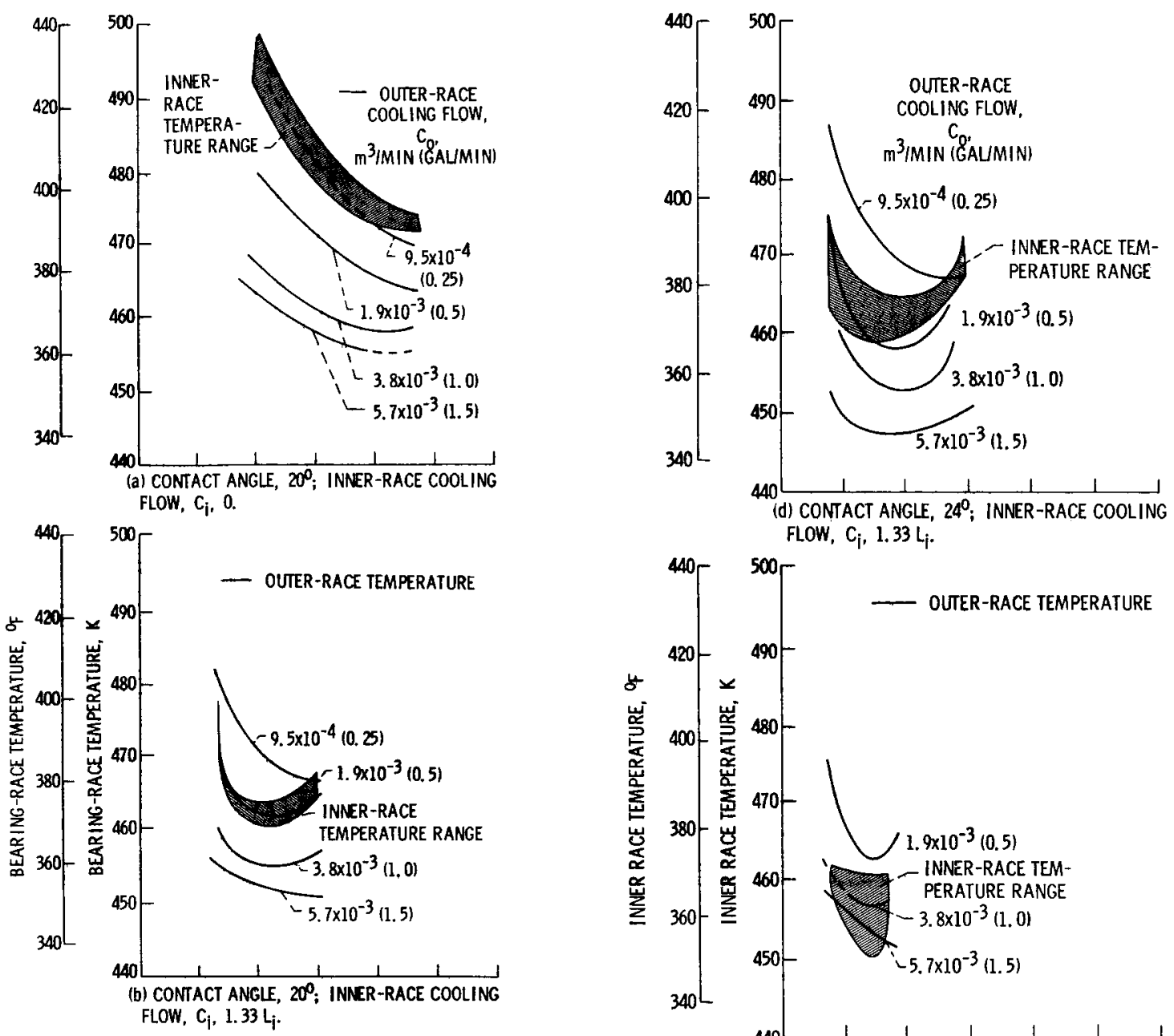
FLOW, $C_{i}, 1.33 L_{i}$
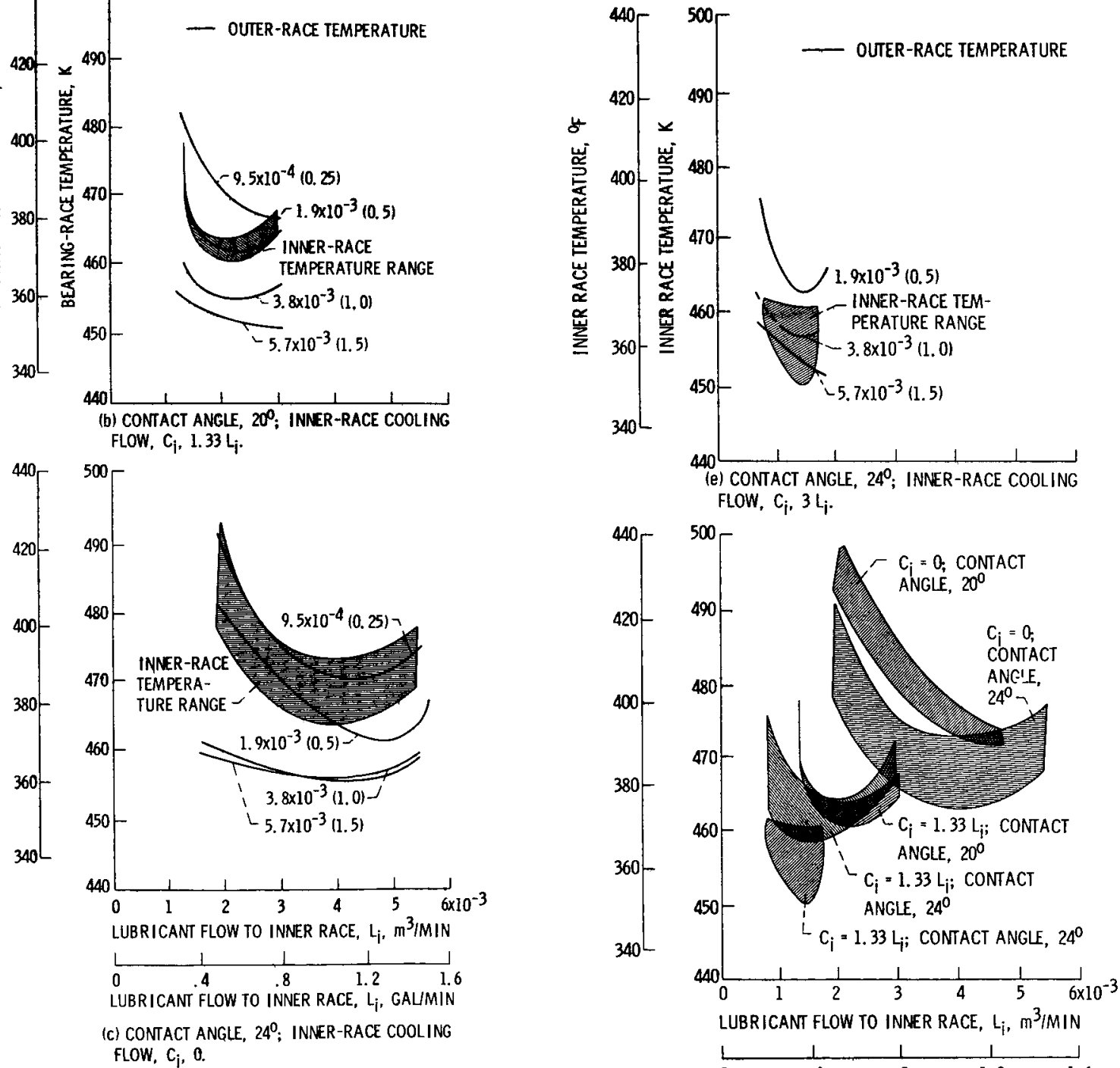

Fig. 9 Bearing race temperature as a function of lubricant flow into bearing, $L_{i}$, for varying inner $\left(C_{1}\right)$ and outer $\left(C_{0}\right)$ race cooling rates. Bearing type, $120-\mathrm{mm}$ bore angular-contact ball bearing; bearing thrust load, $2224 \mathrm{~N}$ $(5000 \mathrm{lb})$; speed, $25000 \mathrm{rpm}\left(3 \times 10^{6} \mathrm{DN}\right)$; oil inlet temperature, $394 \mathrm{~K}\left(250^{\circ} \mathrm{F}\right)$. 


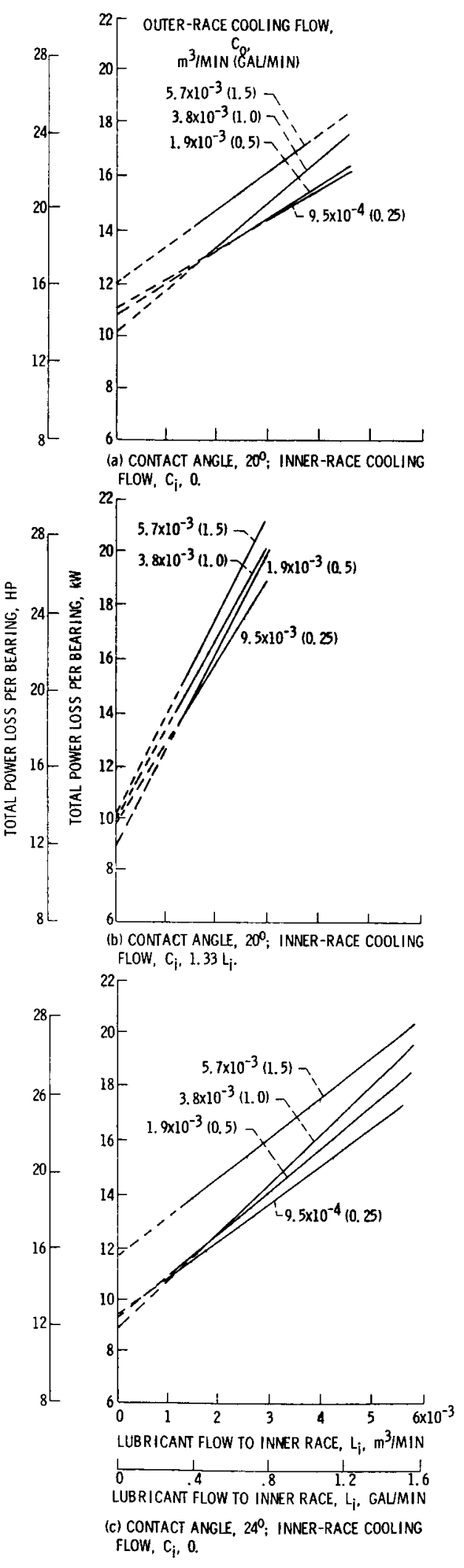

Fig. 10 Bearing power loss as a function of lubricant flow into bearing, $L_{j}$, for varying inner $\left(C_{j}\right)$ and outer $\left(C_{0}\right)$ race cooling rates. Bearing type, $120-\mathrm{mm}$ bore angularcontact ball bearing; bearing thrust load, $22241 \mathrm{~N}$ $(5000 \mathrm{lb})$; speed, $25000 \mathrm{rpm}\left(3 \times 10^{6} \mathrm{DN}\right)$; oil inlet temperature, $394 \mathrm{~K}\left(250^{\circ} \mathrm{F}\right)$
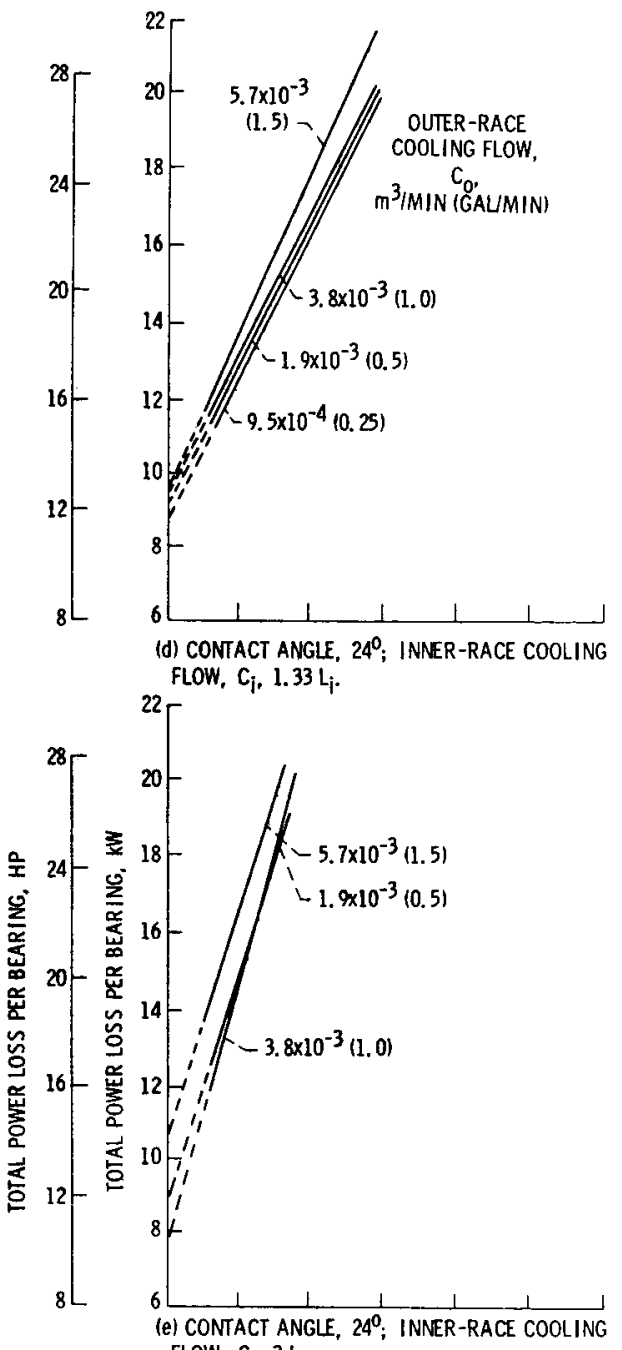
FLOW, $C_{i}, 3 L_{i}$.
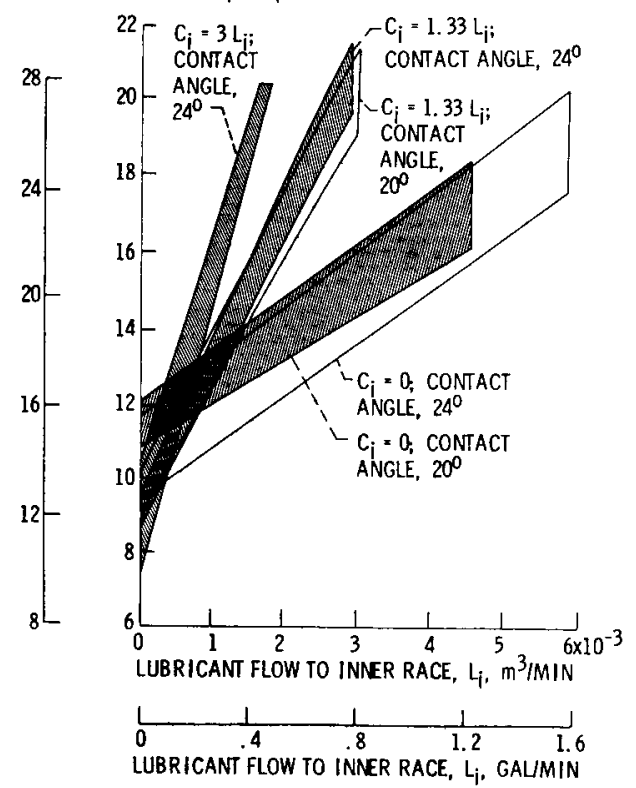

(f) SUMMARY OF BEARING POWER LOSSES.

Fig. 10 Concluded. 